\title{
A COMPARATIVE INVESTIGATION ON THE USE OF RAPESEED OIL AND SOYBEAN OIL IN THE FEEDING OF SWINE
}

\author{
L. Paloheimo, Paavo Roine, and Erkki Uksila, \\ with the technical assistance of \\ Ritva Sirenius, Helle Sauri, and Hilkka Unkila
}

\begin{abstract}
Department of Animal Husbandry and Department of Nutritional Chemistry, University of Helsinki
\end{abstract}

Received July 9. 1959.

In some animals the digestibility of rapeseed oil seems to be exceptionally low as compared with that of other edible oils. In experiments with rats Deuel et al. (3, p. 308) observed that the digestibility percentage of crude rapeseed oil was only 77 and that of refined oil 82 . CARROL (1, p. 202) reports the digestibility percentage 58 from experiments with rats and rabbits, and 61 from experiments with guinea pigs. According to Roine and Uksila (6, p. 11) the digestibility of rapeseed oil is dependent on the age of the rats being lowest in young rats and increasing with age. In man very high figures for the digestibility of rapeseed oil have been obtained. Holmes (ref. Deuel, 2, p. 147) reports a value of $99 \%$ and Deuel et al. (4, p. 369) have arrived at the same figure. In their experiments with swine PALOHEIMO and JанкоцA (5, p. 212) could notice no marked difference in digestibility percentages between rapeseed oil and soybean oil the percentages in both cases being about 100 .

Some investigations on rats (ref. RoINE and UKSILA 6, p. 1) indicate that rapeseed oil and erucic acid, the main fatty acid of the rapeseed oil, may even cause metabolic disorders. The experiments related below were made in order to study whether rapeseed oil, in spite of its normal digestibility, could have an inhibiting effect on the growth of young swine. In addition attention was paid to the food and water consumption and the quality of carcasses.

\section{Arrangement of the experiments}

1st experiment. - After a period of preparative feeding 12 pigs which belonged to 3 different litters were chosen for the experiment. Of these animals 2 groups, $\mathrm{R}$ and $\mathrm{S}$, were formed, $\mathrm{R}$ referring to rapeseed oil and $\mathrm{S}$ to soybean oil. The 3 litters were equally represented in each group. Three of the animals in each group were females 
and 3 castrated. At the end of the preparative period the age of the youngest animals was 76 days and that of the oldest 82 days. The weight of the animals in group $\mathrm{R}$ varied from $22.4-34.8 \mathrm{~kg}$ the average being $27.8 \mathrm{~kg}$. In group $\mathrm{S}$ the corresponding figures were $22.2-32.8$ and 27.5 .

During the preparative period the pigs were gradually accustomed to the oil feeding. They received a mixture of rapeseed oil and soybean oil. Then followed a 27 days period in which the principle of restricted feeding was followed. Each group was kept in a large box the front of which was divided into 6 separate small eating cribs with a trough in each. The pigs had access to the cribs only during meal times. However, two of the cribs were open also between feeding times and the troughs in them were filled with water. During this period of restricted feeding it was planned to give to each of the 10 animals daily as much food as the one with the weakest appetite had eaten on the preceding day. As the two smallest pigs in each group consumed considerably less food than their group fellows, they were fed from the 5th day of the period as sub-groups $\mathrm{Rb}$ and $\mathrm{Sb}$. The other animals formed the sub-groups $\mathrm{Ra}$ and $\mathrm{Sa}$.

The pigs were fed with a concentrate mixture which consisted of $35 \%$ maize meal, $35 \%$ wheat bran, and $30 \%$ skim milk powder. For each $\mathrm{kg}$ concentrate mixture $150 \mathrm{~g}$ oil and $1.5 \mathrm{~kg}$ water were added. Rapeseed oil was given to groups $\mathrm{Ra}$ and $\mathrm{Rb}$, and soybean oil to groups $\mathrm{Sa}$ and $\mathrm{Sb}$. The Food Unit value (Scandinavian) of the whole food mixture was 1.30 per kg and the percentage of digestible crude protein 14.3. The share of oil in the net energy content of the mixture was $34.5 \%$ and the share of total fat correspondingly $40.2 \%$.

The need of A- and D-vitamins was satisfied by use of a concentrated A+Dvitamin preparation. As at the end of the preparative period symptoms of parakeratosis were noticed in all groups, $\mathrm{ZnCl}_{2}$ solution was added to the diet during the experimental periods. The parakeratosis was cured and the animals remained healthy during the rest of the experiment.

After the period of restricted feeding followed a 34 day period of ad libitum feeding. In other respects the feeding remained similar to that of the previous period. The food consumption of the individual animals was controlled during the whole period and the consumption of water during the last 13 days of the experiment separately for groups $\mathrm{R}$ and $\mathrm{S}$.

The animals were weighed once a week.

2nd experiment. - After the period of preparative feeding 10 pigs belonging to 2 litters were chosen for the experiment. Two groups, $\mathrm{R}$ and $\mathrm{S}$ were formed. The animals of these groups belonged equally to the two litters. At the end of the preparative period the age of the youngest animals was 59 days and that of the oldest 71 days. Thus the pigs of the 2 nd experiment were about two weeks younger than those of the 1st. At the said point of time the weight of the animals in group $\mathrm{R}$ varied from $16.0-25.9 \mathrm{~kg}$ the average being $21.6 \mathrm{~kg}$. For group $\mathrm{S}$ the corresponding figures were $15.2-25.9$ and $20.8 \mathrm{~kg}$.

In the keeping and feeding of the animals the same principles as in the 1st experiment were followed. Also the food mixture was the same. As the age difference between the two litters was rather big the animals in both groups were for the 
period of restricted feeding divided into two sub-groups, a and b. Thus there were the following groups: $\mathrm{Ra}, \mathrm{Rb}, \mathrm{Sa}, \mathrm{Sb}$. Each sub-group a contained 3 animals and sub-group b 2 animals. At the end of the preparative period the average weights of the animals in different groups were as follows: Ra $25.1 \mathrm{~kg}, \mathrm{Sa} 24.8 \mathrm{~kg}, \mathrm{Rb} 16.3 \mathrm{~kg}$, Sb $16.8 \mathrm{~kg}$.

The period of restricted feeding lasted 34 days and that of ad libitum feeding 21 days. The consumption of water was controlled throughout the experiment separately for groups $\mathrm{R}$ and $\mathrm{S}$.

The pigs were slaughtered at the close of the experiment and the standard commercial estimation of the carcasses was made. ${ }^{1}$ Samples of hams were taken for determinations of water and fat as well as saponification and iodine numbers. Other samples were taken from different organs and tissues and sent to the department of Pathological Anatomy (prof. H. TEIR) for histological examination.

Table 1. Weight development of the pigs in the 1st experiment $(\mathrm{kg})$.

\begin{tabular}{|c|c|c|c|c|c|c|}
\hline \multirow{2}{*}{\multicolumn{3}{|c|}{$\begin{array}{c}\text { Sign } \\
\text { of the pig }\end{array}$}} & \multicolumn{2}{|c|}{ Restricted feeding } & \multicolumn{2}{|c|}{ Ad lib. feeding } \\
\hline & & & $\begin{array}{c}\text { At the } \\
\text { beginning }\end{array}$ & $\begin{array}{c}\text { On the } \\
27 \text { th day }\end{array}$ & $\begin{array}{l}\text { At the } \\
\text { beginning }\end{array}$ & $\begin{array}{l}\text { On the } \\
34 \text { th day }\end{array}$ \\
\hline & Ra & 1 & 29.0 & 45.3 & 45.3 & 65.0 \\
\hline & $\mathrm{Ra}$ & 2 & 30.0 & 48.5 & 48.5 & 71.5 \\
\hline & $\mathrm{Ra}$ & 3 & 32.0 & 49.3 & 49.3 & 69.5 \\
\hline & $\mathrm{Ra}$ & 4 & 36.0 & 51.8 & 51.8 & 73.5 \\
\hline Average 1 & Ra & & 31.8 & 48.7 & 48.7 & 69.9 \\
\hline & $\mathrm{Rb}$ & 1 & 23.5 & 38.3 & 38.3 & 56.5 \\
\hline & $\mathrm{Rb}$ & 2 & 25.0 & 41.0 & 41.0 & 63.0 \\
\hline Average 1 & $\mathrm{Rb}$ & & 24.3 & 39.7 & 39.7 & 59.8 \\
\hline Average & $\mathbf{R}$ & & 29.3 & 45.7 & 45.7 & 66.5 \\
\hline & $\mathrm{Sa}$ & 1 & 28.0 & 47.0 & 47.0 & 70.5 \\
\hline & $\mathrm{Sa}$ & 2 & 29.0 & 45.7 & 45.7 & 66.5 \\
\hline & $\mathrm{Sa}$ & 3 & 32.0 & 48.0 & 48.0 & 71.0 \\
\hline & Sa & 4 & 34.0 & 51.0 & 51.0 & 71.0 \\
\hline Average : & $\mathrm{Sa}$ & & 30.8 & 47.9 & .47 .9 & 69.8 \\
\hline & $\mathrm{Sb}$ & 1 & 23.3 & 36.0 & 36.0 & 59.0 \\
\hline & $\mathrm{Sb}$ & 2 & 25.7 & 40.0 & 40.0 & 60.0 \\
\hline Average & $\mathrm{Sb}$ & & 24.5 & 38.0 & 38.0 & 59.5 \\
\hline Average & $\mathrm{S}$ & & 28.7 & 44.6 & 44.6 & 66.3 \\
\hline
\end{tabular}

1 This estimation was made by J. PARTAnen, M.S. from the Pig Husbandry Experiment Station. 
Table 2. Weight development of the pigs in the 2nd experiment $(\mathrm{kg})$.

\begin{tabular}{|c|c|c|c|c|c|c|}
\hline \multirow{2}{*}{\multicolumn{3}{|c|}{$\begin{array}{l}\text { Sign } \\
\text { of the pig }\end{array}$}} & \multicolumn{2}{|c|}{ Restricted feeding } & \multicolumn{2}{|c|}{ Ad lib. feeding } \\
\hline & & & \multirow{2}{*}{$\begin{array}{c}\text { At the } \\
\text { beginning }\end{array}$} & \multirow{2}{*}{$\begin{array}{c}\text { On the } \\
34 \text { th day } \\
\mathbf{4 8 . 5}\end{array}$} & \multirow{2}{*}{$\begin{array}{c}\text { At the } \\
\text { beginning }\end{array}$} & \multirow{2}{*}{$\begin{array}{c}\text { On the } \\
\text { 21st day } \\
63.0\end{array}$} \\
\hline & $\mathrm{Ra}$ & 11 & & & & \\
\hline & $\mathrm{Ra}$ & 12 & 30.0 & 52.5 & 52.5 & 70.5 \\
\hline & $\mathrm{Ra}$ & 13 & 31.5 & 54.0 & 54.0 & 72.0 \\
\hline Average & $\mathrm{Ra}$ & & 30.3 & 51.7 & 51.7 & 68.5 \\
\hline & $\mathrm{Rb}$ & 11 & 19.5 & 40.0 & 40.0 & 57.5 \\
\hline & $\mathrm{Rb}$ & 12 & 19.5 & 39.5 & 39.5 & 55.0 \\
\hline Average & $\mathrm{Rb}$ & & 19.5 & 39.8 & 39.8 & 56.3 \\
\hline Average & $\mathrm{R}$ & & 26.0 & 46.9 & 46.9 & 63.2 \\
\hline & $\mathrm{Sa}$ & 11 & 29.5 & 52.5 & 52.5 & 72.5 \\
\hline & $\mathrm{Sa}$ & 12 & 30.5 & 51.0 & 51.0 & 76.5 \\
\hline & $\mathrm{Sa}$ & 13 & 31.0 & 54.5 & 54.5 & 75.0 \\
\hline Average & $\mathrm{Sa}$ & & 30.3 & 52.7 & 52.7 & 74.7 \\
\hline & $\mathrm{Sb}$ & 11 & 20.0 & 43.5 & 43.5 & 67.0 \\
\hline & $\mathrm{Sb}$ & 12 & 23.0 & 47.0 & 47.0 & 69.0 \\
\hline Average & $\mathrm{Sb}$ & & 21.5 & 45.3 & 45.3 & 68.0 \\
\hline Average & $\mathrm{s}$ & & 26.8 & 49.7 & 49.7 & 72.0 \\
\hline
\end{tabular}

\section{Results and Discussion}

Tables 1 and 2 show the weight development of the pigs. Tables 3 and 4 give the average food consumption per pig per day in the different sub-groups and groups. Table 5 shows the average weight increment per day per animal, and the consumption of Food Units per kg weight increment.

The results shown in the Tables indicate that there may be a slight difference between rapeseed oil and soybean oil in their effects on swine. During the restricted feeding the weight increment of the animals was almost the same irrespective of the kind of oil received in the food. During the ad libitum feeding in the second experiment the animals receiving soybean oil showed a better appetite than their mates which received rapeseed oil. Correspondingly also the weight increment of the former group was greater. In the first experiment, however, such a difference was hardly noticeable.

As mentioned above, in the 1st experiment the consumption of drinking water was controlled for all the groups during a 13 day period. During this time the animals of group $\mathrm{R}$ consumed $5.5 \mathrm{~kg}$ water per day per animal the corresponding figure for group $\mathrm{S}$ being $4.5 \mathrm{~kg}$. The total water consumption (drinking water + the water 
Table 3. Food consumption in Food Units per day per pig in different groups of the lst experiment.

\begin{tabular}{ccc}
\hline $\begin{array}{c}\text { Sub-group } \\
\text { or group }\end{array}$ & $\begin{array}{c}\text { Restricted feeding } \\
27 \text { days }\end{array}$ & $\begin{array}{c}\text { Ad lib. feeding } \\
34 \text { days }\end{array}$ \\
\hline $\mathrm{Ra}$ & 1.75 & 3.02 \\
$\mathrm{Rb}$ & 1.41 & 2.44 \\
$\mathrm{R}$ & 1.64 & 2.83 \\
\hline $\mathrm{Sa}$ & 1.75 & 3.17 \\
$\mathrm{Sb}$ & 1.37 & 2.77 \\
$\mathrm{~S}$ & 1.62 & 3.04 \\
\hline
\end{tabular}

Table 4. Focd consumption in Focd Units per day per pig in different groups of the 2nd experiment.

\begin{tabular}{ccc}
\hline $\begin{array}{c}\text { Sub-group } \\
\text { or group }\end{array}$ & $\begin{array}{c}\text { Restricted feeding } \\
\text { 34 days }\end{array}$ & $\begin{array}{c}\text { Ad lib. feeding } \\
\text { 21 days }\end{array}$ \\
\hline $\mathrm{Ra}$ & 2.12 & 3.23 \\
$\mathrm{Rb}$ & 1.69 & 3.10 \\
$\mathrm{R}$ & 1.94 & 3.18 \\
\hline $\mathrm{Sa}$ & 2.19 & 3.93 \\
$\mathrm{Sb}$ & 1.72 & 3.63 \\
$\mathrm{~S}$ & 2.00 & 3.81 \\
\hline
\end{tabular}

Table 5. Weight increment per day per animal, and the consumption of Food Units per kg weight increment.

\begin{tabular}{ccccc}
\hline & & $\begin{array}{c}\text { Weight increment, kg., } \\
\text { per day per animal }\end{array}$ & \multicolumn{2}{c}{$\begin{array}{c}\text { Food Units per kg. } \\
\text { weight increment }\end{array}$} \\
\cline { 2 - 5 } & $\begin{array}{c}\text { Restricted } \\
\text { feeding }\end{array}$ & $\begin{array}{c}\text { Ad lib. } \\
\text { feeding }\end{array}$ & $\begin{array}{c}\text { Restricted } \\
\text { feeding }\end{array}$ & $\begin{array}{c}\text { Ad lib. } \\
\text { feeding }\end{array}$ \\
\hline 1st experiment & & & & \\
$\mathrm{R}$ & 0.586 & 0.743 & 2.80 & 3.81 \\
$\mathrm{~S}$ & 0.568 & 0.775 & 2.85 & 3.92 \\
\hline 2nd experiment & & & & \\
$\mathrm{R}$ & 0.597 & 0.795 & 3.25 & 4.00 \\
$\mathrm{~S}$ & 0.654 & 1.061 & 3.06 & 3.59 \\
\hline
\end{tabular}


Table 6. Water consumption in the 2nd experiment, kg per day per animal, and per Food Unit.

\begin{tabular}{|c|c|c|c|c|c|c|}
\hline \multirow[b]{2}{*}{ Group } & \multicolumn{3}{|c|}{ Restricted feeding } & \multicolumn{3}{|c|}{ Ad lib. feeding } \\
\hline & $\begin{array}{c}\text { Drinking } \\
\text { water }\end{array}$ & $\begin{array}{l}\text { Total } \\
\text { water }\end{array}$ & $\begin{array}{c}\text { Total } \\
\text { water per } \\
\text { F. U. }\end{array}$ & $\begin{array}{c}\text { Drinking } \\
\text { water }\end{array}$ & $\begin{array}{c}\text { Total } \\
\text { water }\end{array}$ & $\begin{array}{c}\text { Total } \\
\text { water per } \\
\text { F. U. }\end{array}$ \\
\hline
\end{tabular}

$\begin{array}{lllllll}\mathrm{R} & 3.82 & 6.21 & 3.20 & 4.55 & 8.36 & 2.63 \\ \mathrm{~S} & 3.07 & 5.55 & 2.78 & 4.21 & 8.80 & 2.31\end{array}$

Table 7. Figures pertaining to the commercial evaluation of the carcasses. (Average figures for groups $\mathrm{R}$ and $\mathrm{S}$ of the 2 nd experiment.)

\begin{tabular}{ccccc}
\hline Group & $\begin{array}{c}\text { Slaughter } \\
\text { weight kg }\end{array}$ & $\begin{array}{c}\text { Loss in weight } \\
\text { at slaughter, \% }\end{array}$ & $\begin{array}{c}\text { Thickness of } \\
\text { back fat cm }\end{array}$ & $\begin{array}{c}\text { Distribution of } \\
\text { back fat, points }\end{array}$ \\
\hline $\mathrm{R}$ & 46.4 & 25.5 & 2.6 & 10.3 \\
$\mathrm{~S}$ & 54.4 & 24.8 & 3.2 & 10.1 \\
\hline
\end{tabular}

Table 8. Data concerning the chemical composition and fat quality of the samples taken from the carcasses. (Average figures for groups $\mathrm{R}$ and $\mathrm{S}$ in the 2 nd experiment.)

\begin{tabular}{|c|c|c|c|c|c|c|}
\hline \multirow{2}{*}{ Group } & \multicolumn{2}{|c|}{ In adipose tissue } & \multicolumn{2}{|c|}{$\begin{array}{l}\text { In meat beneath } \\
\text { the fat layer }\end{array}$} & \multirow{2}{*}{$\begin{array}{l}\text { Saponi- } \\
\text { fication } \\
\text { number }\end{array}$} & \multirow{2}{*}{$\begin{array}{c}\text { Iodine } \\
\text { number }\end{array}$} \\
\hline & $\begin{array}{c}\text { Water } \\
\%\end{array}$ & $\begin{array}{c}\text { Fat } \\
\%\end{array}$ & $\begin{array}{c}\text { Water } \\
\%\end{array}$ & $\begin{array}{c}\text { Fat } \\
\%\end{array}$ & & \\
\hline $\mathbf{R}$ & 10.9 & 81.8 & 68.1 & 8.3 & 187 & 85.3 \\
\hline S & 10.5 & 81.6 & 66.2 & 9.5 & 190 & 96.7 \\
\hline
\end{tabular}

consumed with food) was in group R $8.7 \mathrm{~kg}$ and in group S $7.9 \mathrm{~kg}$ per day per animal. The water consumption per Food Unit was, correspondingly, $3.1 \mathrm{~kg}$ and $2.5 \mathrm{~kg}$. The consumption of drinking water was, on every controlled day, considerably greater in group $\mathrm{R}$ than in group $\mathrm{S}$. The variation per pig in the figures in the former group was $4.9-6.0 \mathrm{~kg}$ and in the latter $3.7-4.9 \mathrm{~kg}$.

In the 2nd experiment the consumption of drinking water was controlled for all the groups during the whole experiment. Table 6 shows some average figures pertaining to the water consumption in the 2 nd experiment. The difference in the water consumption seems to be caused by the difference in the diet.

In the 1st experiment during the last 13 days when the consumption of the drinking water was controlled the rapeseed oil pigs consumed clearly more water than their mates, and in the 2nd experiment, where the water consumption was controlled during the whole experiment, the consumption of total water was slightly greater in the soybean oil group during the ad libitum feeding. The consumption of total water calculated per Food Unit in the rapeseed oil group of the 2nd experi- 
ment was during both periods greater than in the soybean oil group. The fact that the water consumption of the experimental animals during the 1st experiment was in general greater than during the 2 nd experiment evidently depends upon the higher temperature in the barn during the 1st experiment.

Table 7 shows some figures pertaining to the commercial evaluation of the carcasses.

The average figures of the results of the chemical analyses are given in Table 8 . The variation of the saponification number in group $\mathrm{R}$ was $186-189$ and of the iodine number 75.8-91.1. For group $\mathrm{S}$ the corresponding variations were $188-191$ and $94.9-98.8$.

In the histological examination of the organs and tissues no difference between the $\mathrm{R}$ and $\mathrm{S}$ animals could be detected. However, harmful effects of too great a share of fat in the diet in general could be detected in all experimental animals. ${ }^{1}$

\section{$S u m m$ ary}

For the purpose of comparing the effects of rapeseed oil and soybean oil on the weight increment and thriving of young pigs two experiments were performed. The first experiment was made with 12 and the second with 10 pigs divided into two groups, groups $\mathrm{R}$ receiving rapeseed oil and groups $\mathrm{S}$ receiving soybean oil in their food. The share of added oil in the net energy content of the food mixture was $34.5 \%$. Each experiment was divided into a period of restricted feeding and a period of ad libitum feeding. During the restricted feeding no marked differences between the two groups could be noticed, but during the ad libitum feeding in the second experiment the animals of group $\mathrm{S}$ showed a better appetite and a more rapid weight development than their mates in group $\mathrm{R}$. In addition, there was a difference in the consumption of drinking water between the two groups in each experiment. The animals of groups $\mathrm{R}$ consumed more water than their mates. In the investigation of the bodies after slaughtering no differences were noticeable between the groups.

1 The results of the histological investigations are to be published separately in the near future by P. Roine, E. UKsila, H. Teir and J. Rapol.

\section{REFER E C E S}

(1) CArrol, K. K. 1957. Rape oil and cholesterol metabolism in different species with reference to experimental atherosclerosis. Proc. Soc. Exptl. Biol. Med. 94: 202-205.

(2) Deuel, H. J., Jr. 1954. Nutritional significance of the fats. Progress in the chemistry of fats and other lipids. Edited by R. T. Holman \& W. O. Lundberg \& T. Malkin. 2: 99-192. London.

(3) - Greenberg, S. M., Straub, E. E., Jue, D., Gooding, C. M. \& Brown, C. F. 1948. Studies on the comparative nutritive value of fats, X. J. Nutrition $35: 301-314$.

(4) - Johnson, R. M., Calbert, C. E., Gardner, J. \& Thomas, B. 1949. Studies on the comparative nutritive value of fats, XII. Ibid. $38: 369-379$.

(5) Paloheimo, L. \& Jahkola, Berit. 1959. Digestibility of soybean oil and rape oil by swine. J. of the Scient. Agric. Society of Finland 31:212-214

(6) Roine, PaAvo \& Uksila, ERKкi. 1958. Experiments on Feeding Rats with Rapeseed oil. Acta agr. fennica 94, 11:2-13. 


\title{
VERTAILEVA TUTKIMUS RYPSIÖLJYN JA SOIJAÖLJYN VAIKUTUKSESTA SIKOJEN RUOKINNASSA.
}

\author{
L. Paloheimo, PaAvo Roine ja Erkki Uksila
}

Teknillisinä avustajina Ritva Sirenius, Helle Sauri ja Hilkka Unkila

Yliopiston kotieläintieteen laitos ja Yliopiston ravintokemian laitos

Muualla suoritetut tutkimukset ovat osoittaneet, että rypsiöljy eräitten eläinlajien ravintoon lisättynä ei ole samanarvoinen muihin kasvirasvoihin verrattuna. Rotilla, kaniineilla ja marsuilla suoritetuissa kokeissa sen sulavuus on osoittautunut melkoisesti huonommaksi kuin muiden kasviöljyjen. Lisäksi eräissä rotilla suoritetuissa kokeissa on ilmennyt, että rypsiöljyllä on suoranaisia normaalista aineenvaihduntaa häiritseviä vaikutuksia. Näiden vaikutusten katsotaan johtuvan erukahaposta, jota rypsiöljyn rasvahapoista on n. $50 \%$.

PALOHEImon ja JАнкоLan suorittamissa kokeissa (5) ilmeni, että rypsiöljym ruoansulatuksellinen hyväksikäyttö oli 100-prosenttinen. Käsillä olevan tutkimuksen tarkoituksena oli selvittää, olisiko rypsiöljyllä tästä huolimatta huonompi vaikutus sikojen painonlisäykseen kuin erukahappovapaalla kasviöljyllä. Vertailuöljyksi valittiin soijaöljy. Tutkimus jakautui kahteen erilliseen kokeeseen. Kummassakin kokeessa oli öljylisäyksen osuus rehuannoksen nettoenergiasisällössä $34.5 \%$. Toisessa näistä kokeista osoittautuivat vertailtavien öljylajien vaikutukset eläinten ruokahaluun ja painonlisäykseen miltei samanlaisiksi, mutta toisessa kokeessa oli soijaöljyä saaneiden eläinten ruokahalu parempi ja painonlisäys jonkinverran suurempi kuin rypsiöljyä saaneiden. Kummassakin kokeessa kävi ilmi, että rypsiöljyä saaneet porsaat kuluttivat juomavettä enemmän kuin vertailueläimet. Ruhojen laatuominaisuuksissa ei havaittu eroja eri ryhmien kesken. Myöskin kudosrasyan jodiluku ja saippuoitumisluku olivat rypsiöljyä saaneilla eläimillä samaa suuruusluokkaa kuin vertailueläimillä. 